E-ISSN. 2685-7650

Vol 3 No 2 (2021) pp 80-91

Artikel Disubmit 3 Maret $2021 \bullet$ Revisi 23 April $\bullet$ Revisi Diterima 10 Juli

\title{
Optimalisasi Pusat Layanan Migrasi Desmigratif di Masa Pandemi Covid-19
}

\author{
Ai Rahmayanti \\ Program Doktor Ilmu Pemerintahan, Institut Pemerintahan Dalam Negeri \\ Email: airahmayanti@gmail.com
}

\begin{abstract}
To reduce the problems that befall the Indonesian Migrant Workers/Pekerja Migran Indonesia (PMI), the government formulate a program called Desa Migran Produktif or commonly known as Desmigratif, which formulated for 400 chosen village over Indonesia. One of the pillars that support the program is the existence of an Information Service Centre (Pusat Layanan Informasi) that can be accessed by PMI, prospective of PMI, and their relative. The performance of Desmigratif officers in operating the Information Service Center is increasingly challenging, specially during the Covid - 19 Pandemic. Spessificaly in optimizing government communication used by the officials and all relevant stakeholders. The purpose of this research is to examine the optimization efforts done by Desmigratif workers in service operation of the Information Service Center during the Covid-19 pandemic. The method used is a qualitative that can be further explored to discuss the topic of government communication in efforts to optimize services during the pandemi. The results showed that the services are adaptive to the times and follow the technological developments and appropriate especially during the pandemic, where the opportunity to communicate directly very limited. Furthermore, another thing that also affects are the improvement of the quality and competence of the Desmigatif offical and the collaborations that built with related parties.
\end{abstract}

Keywords: government communication; desmigratif; Indonesian Migrant Workers

\begin{abstract}
Abstrak: Dalam rangka mengurangi berbagai permasalahan yang menimpa kalangan Pekerja Migran Indonesia (PMI), pemerintah merancang program yang bernama Desa Migran Produktif atau biasa disebut Desmigratif, yang dirancang untuk 400 desa terpilih di seluruh Indonesia. Salah satu pilar yang menopang program ini adalah adanya Pusat Layanan Informasi yang bisa diakses oleh para PMI, calon PMI dan keluarganya. Kinerja petugas Desmigratif dalam mengoperasikan Pusat Layanan Informasi semakin bertambah tantangannya, terlebih pada masa pandemi Covid - 19. Khususnya dalam optimalisasi komunikasi pemerintahan yang digunakan oleh para petugas dan seluruh stakeholder terkait. Tujuan dari penelitian ini adalah untuk mengkaji upaya optimalisasi yang dilakukan oleh pekerja Desmigratif dalam operasional pelayanan Pusat Layanan Informasi di masa pandemi Covid - 19. Adapun metode yang digunakan adalah metode kualitatif yang dapat ditelaah lebih jauh untuk mendiskusikan topik komunikasi pemerintahan dalam upaya optimalisasi pelayanan selama masa pandemi. Hasil penelitian menunjukkan bahwa pelayanan yang adaptif dengan zaman dan mengikuti perkembangan teknologi, tepat dilakukan terlebih pada masa pandemi, dimana kesempatan untuk berkomunikasi secara langsung sangat terbatas. Selanjutnya, hal lain yang turut memengaruhi adalah peningkatan kualitas dan kompetensi individu para pekerja Desmigratif serta kolaborasi yang dibangun dengan pihak-pihak yang terkait.
\end{abstract}

Kata Kunci: komunikasi pemerintahan; desmigratif; Pekerja Migran Indonesia

\section{Pendahuluan}

Jumlah Pekerja Migran Indonesia (PMI) dari tahun ke tahun terus mengalami peningkatan. Pada tahun 2016 terdapat 234.451 PMI yang ditempatkan, kemudian tahun 2017 sebanyak 262.899 PMI, dan tahun 2018 total PMI yang ditempatkan ada sebanyak 283.640 orang (Bnp2tki, 2018). Kondisi demikian menempatkan PMI sebagai salah satu penyumbang 
devisa negara terbesar, meskipun pada realitasnya hal tersebut berbanding terbalik dengan mayoritas kehidupan para PMI yang bersangkutan.

Menurut data BNP2TKI, terdapat 4.696 pengaduan yang diajukan PMI di crisis center selama Tahun 2018. Jenis permasalahan dari aduan yang dilakukan sangat variatif, mulai dari permasalahan PMI tidak berdokumen, perbudakan PMI oleh majikan atau agen penyalur, penipuan, berbagai bentuk kekerasan sampai pada hilangnya nyawa PMI, dan lain sebagainya. Meskipun pada satu sisi, bekerja menjadi Pekerja Migran Indonesia memiliki sisi positif, yaitu mendapatkan gaji yang lebih tinggi dibandingkan di Indonesia, memiliki jaringan yang lebih luas dikarenakan melibatkan orang-orang dari berbagai negara, namun fakta-fakta permasalahan seperti yang ditemukan di atas tidak dapat dibiarkan.

Dalam rangka menyikapi permasalahan-permasalahan tersebut, pemerintah Indonesia mencanangkan suatu program yang diberi nama Desa Migran Produktif atau disingkat Desmigratif. Program ini ditetapkan pada tanggal 1 Maret 2019 dan diatur dalam Peraturan Menteri Ketenagakerjaan Nomor 2 Tahun 2019 tentang Pemberdayaan Komunitas Pekerja Migran Indonesia di Desa Migran Produktif. Menurut Pasal 1 angka 5 Permenaker Ketenagakerjaan Nomor 2 Tahun 2019, Desa Migran Produktif yang selanjutnya disebut Desmigratif adalah Desa Migran yang telah ditetapkan sebagai penerima program pemberdayaan Komunitas Pekerja Migran Indonesia (Kemnaker, 2019a).

Kementerian Ketenagakerjaan merencanakan untuk membentuk dan memfasilitasi 400 desa terpilih yang tersebar di seluruh Indonesia dan ditetapkan sebagai Desa Migran Produktif. Dalam pelaksanaannya, program Desmigratif pertama kali diluncurkan pada tahun 2016, dengan melibatkan dua desa sebagai percontohan. Selanjutnya, terdapat 122 desa yang telah dibina selama tahun 2017, kemudian terdapat 130 desa binaan yang tersebar di 87 kabupaten dan 12 provinsi selama tahun 2018, dan tahun 2019 terdapat 402 Desmigratif yang sudah dibangun (Kurniawan, 2019).

Studi ini merupakan kajian mengenai Desa Migran Produktif (Desmigratif) yang berfokus pada kajian seputar hubungan antara masyarakat (yang diperintah) dengan Pemerintah (yang memerintah). Program yang merupakan upaya pemerintah yakni Kementerian Ketenagakerjaan ini, dikhususkan untuk melindungi pekerja migran dan keluarganya sejak dari desa. Program ini menuntut peran aktif pemerintah sampai pada tingkat satuan unit terkecil, yakni pemerintah desa, dalam menyediakan layanan informasi, memberdayakan potensi desa, mengelola koperasi desa, hingga pendidikan anak-anak pekerja migran.

Program desmigratif menegaskan konsep penanganan desa yang menjadi kantong pekerja migran agar mampu beroperasi secara terpadu dan terintegrasi dengan melibatkan kementerian/lembaga terkait untuk memberdayakan, melindungi dan melayani pekerja migran beserta keluarganya dimulai dari desa. Selain itu, desmigratif juga diperuntukkan untuk meningkatkan pelayanan serta memberi perlindungan bagi Calon PMI/PMI di desa yang menjadi kantong PMI (desa pengirim PMI terbanyak) dengan menawarkan program-program unggulan yang dibutuhkan oleh yang bersangkutan dan keluarganya melalui pemanfaatan potensi lokal dengan tidak mengabaikan karakteristik daerah setempat.

Sasaran dari Desmigratif, berdasarkan pedoman program dari Kementerian Ketenagakerjaan Republik Indonesia Tahun 2018, adalah melayani, melindungi dan memberdayakan CPMI/PMI dan keluarganya sejak dari dan kembali ke Daerah asal, dengan kriteria peserta sebagai berikut: 
a) Calon PMI yaitu PMI yang akan berangkat ke luar negeri;

b) Keluarga PMI yaitu Suami/Istri atau Anak atau Ayah/Ibu dari PMI yang sedang bekerja di Luar Negeri;

c) PMI Purna yaitu PMI yang sudah tidak bekerja di Luar Negeri dan telah kembali ke Daerah asal paling lama 3 (tiga) tahun setelah kepulangan.

Selanjutnya, pelaksanaan Desmigratif harus bersandarkan pada prinsip penyelenggaraannya. Prinsip-prinsip tersebut di antaranya:

a) Kolaboratif: pelaksanaannya bekerjasama, bersinergi dan terintegrasi dengan berbagai kegiatan dan program yang terkait dari para pemangku kepentingan;

b) Partisipatif: masyarakat terlibat secara aktif dalam proses perencanaan, pelaksanaan, pemanfaatan dan pengawasan;

c) Berkelanjutan: setiap pengambilan keputusan dalam penyelenggaraan program Desmigratif harus mempertimbangkan peningkatan kesejahteraan TKI dan keluarganya tidak hanya saat ini tetapi juga di masa depan.

Sementara itu, bangunan Desmigratif ditopang oleh empat pilar, yakni:

a) Pusat layanan migrasi; Diberikan kepada orang atau warga desa yang hendak berangkat ke Luar Negeri dengan cara mendapatkan pelayanan di balai desa atau diluar kantor desa melalui peran dari Pemerintah Desa dan petugas Desmigratif.

b) Usaha produktif; Kegiatan ini dimaksudkan untuk membantu PMI dan keluarganya agar mereka memiliki keterampilan dan kemauan untuk membangun usaha-usaha produktif. Ruang lingkup kegiatannya mencakup penelusuran potensi unggulan desa, pelatihan untuk usaha produktif, tenaga pendampingan untuk usaha produktif, bantuan peralatan sarana produktif sampai tahap pemasarannya, sehingga ketika PMI yang bekerja di Luar Negeri mengirimkan remittance atau sudah kembali ke desa maka sudah ada basis usaha produktif yang bisa di bangun oleh PMI beserta keluarganya.

c) Pengasuhan anak secara bersama; atau disebut juga dengan community parenting. Dengan kegiatan ini anak-anak PMI diasuh bersama-sama oleh masyarakat dalam suatu pusat belajar mengajar.

d) Koperasi; yang dalam pelaksanaannya memerlukan proses pembelajaran dan kreativitas. Koperasi usaha produktif ini tentunya juga bisa menjadi inisiatif bersama dari masyarakat yang akan didukung oleh Pemerintah. 


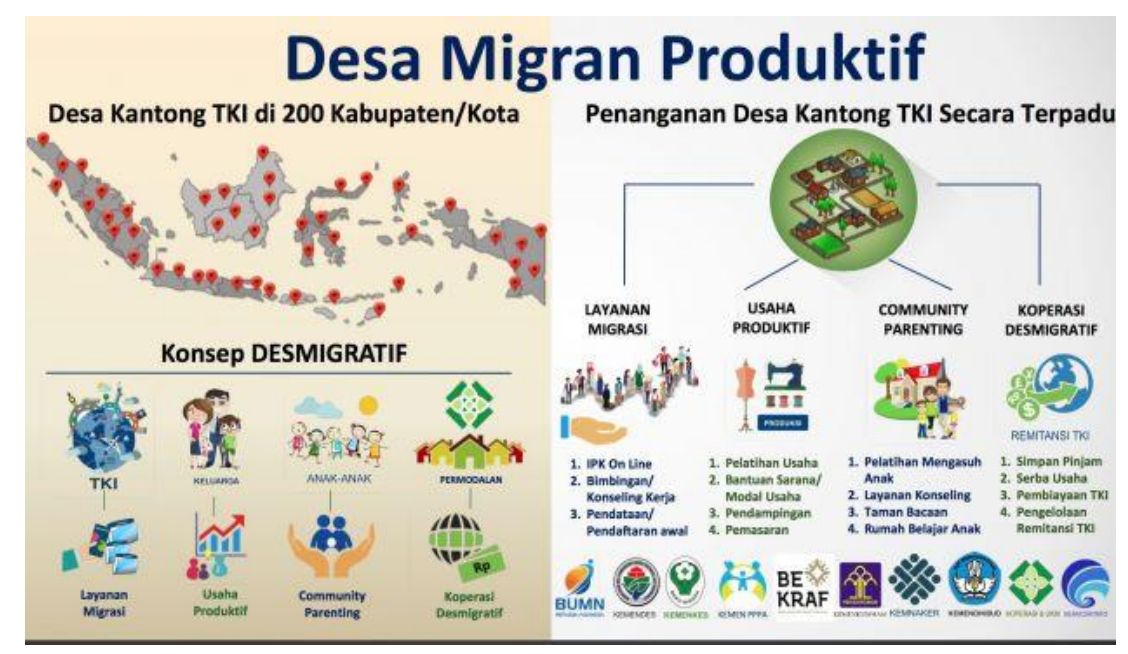

Gambar 1.1: Skema Desa Migran Produktif (Desmigratif)

Tulisan ini akan membahas hanya pada pilar pertama yaitu pusat layanan migrasi, khususnya yang berkaitan dengan kerja-kerja optimalisasi pemberian layanan selama masa pandemi Covid-19. Lebih jauh lagi, kondisi tersebut penulis kaitkan dengan komunikasi pemerintahan yang dilakukan oleh petugas Desmigratif kepada para komunikannya.

Berdasarkan kualifikasi dan mekanisme pengusulan yang telah disusun oleh Kementerian Ketenagakerjaan Republik Indonesia, petugas Desmigratif merupakan purna PMI atau siapa saja warga desa setempat yang memiliki kepedulian terhadap isu PMI, berjiwa sosial, aktif, bersemangat, serta memiliki motivasi untuk menjadi fasilitator dalam pelaksanaan empat pilar Desmigratif. Selain itu, petugas Desmigratif juga dituntut untuk memiliki pengalaman organisasi dan pemberdayaan dalam kegiatan sosial, mampu mengoperasikan aplikasi/sistem di komputer, dan bertanggung jawab untuk mengelola akun di Sistem Informasi Desmigratif (Sistif). Satu desa hanya memiliki satu petugas Desmigratif, yang selanjutnya diusulkan oleh masing-masing kepala desa sebagai penanggung jawab (PJ) program di desa kepada Disnaker kabupaten/kota (Kemnaker, 2019b).

Dalam melaksanakan peran dan tugasnya yang berkaitan dengan pilar pusat layanan migrasi, petugas Desmigratif mempunyai tanggung jawab untuk membagikan beberapa informasi kepada orang atau warga desa yang hendak berangkat ke Luar Negeri. Informasi tersebut diantaranya adalah informasi pasar kerja, bimbingan kerja, dan informasi mengenai bekerja ke Luar Negeri, termasuk pengurusan dokumen awal. Selain itu, menurut penelitian Putri \& Nugroho (2020) petugas Desmigratif biasanya juga memberikan informasi-informasi diluar pasar kerja yaitu mengenai pembuatan KIS dan BPJS, sehingga selain berperan sebagai petugas Desmigratif juga berperan sebagai Layanan Masyarakat.

Seluruh informasi yang disampaikan tersebut, diberikan secara lisan dengan metode sosialisasi dan biasanya berlangsung di kantor desa, dilakukan secara door to door, atau ditempat-tempat tertentu yang menjadi pusat berkumpulnya warga desa. Cara lain yang biasanya digunakan adalah dengan memanfaatkan fasilitas penunjang layanan migrasi dari Kementerian Ketenagakerjaan, berupa pamflet mengenai tata cara pemberangkatan PMI yang dilengkapi dengan gambar-gambar sehingga calon PMI akan lebih mudah menyerap informasi yang diberikan oleh Petugas Desmigratif (Putri \& Nugroho, 2020). 
Namun demikian, pemberian informasi pada pelaksanaan layanan migrasi ini tentu masih meninggalkan beberapa catatan, khususnya jika melihat lebih banyak pelaksanaan di Desmigratif lainnya di seluruh Indonesia. Penelitian Awwal et al. (2020) mengenai pelaksanaan Program Desmigratif di Desa Karya Mukti Kabupaten Ciamis menunjukkan bahwa layanan migrasi tidak berjalan dengan optimal. Hal tersebut disebabkan oleh kurangnya komunikasi dan koordinasi yang dilakukan antara PJ desa (kepala desa) dengan petugas Desmigratif. Selain itu, terdapat pula faktor minimnya kemampuan dan pengalaman petugas dalam memberikan sosialisasi atau pelayanan informasi kepada masyarakat sehingga banyak informasi yang terlewatkan oleh para calon PMI.

Penelitian di atas berbeda dengan apa yang ditemukan oleh Fitriani et al. (2020). Dalam penelitiannya di Desa Jepara Kabupaten Lampung Timur, pilar layanan migrasi masih menjadi pilar yang berjalan dari mulai Desmigratif terbentuk di desa tersebut yakni tahun 2017 sampai saat penelitian dilakukan. Hal tersebut menunjukkan bahwa kerja-kerja petugas pada pilar ini masih terus berlangsung. Selanjutnya, penelitian Karyati \& Adiwirahayu (2018) yang menyebutkan bahwa beberapa upaya petugas desmigratif dalam menjalankan pilar layananmigrasi adalah dengan melakukan sosialisasi, memberikan informasi, dan menyediakan fasilitas penunjang informasi tersebut.

Beban kerja para petugas Desmigratif, baik yang lancar maupun yang masih terkendala oleh beberapa hambatan, pada satu momentum yang sama mengalami tantangan yang sangat berat. Momen tersebut adalah muncul dan masih berlangsungnya pandemi Covid-19 yang melanda seluruh dunia, tidak terkecuali Indonesia. Jika dilihat dari teori The Laswell Formula, para petugas Desmigratif (komunikator) yang harus selalu mentransfer informasi kepada para calon PMI (komunikan), harus mengupayakan opsi media atau cara alternatif untuk menyampaikan pesan agar pesan tersebut menghasilkan efek atau dampak terhadap keberhasilan layanan migrasi yang dilaksanakan.

Ikrimah et al. (2020) menyebutkan bahwa masa pandemi Covid-19 menyebabkan para petugas Desmigratif tidak bisa terjun langsung dalam praktik pelaksanaan dan pendampingan program. Opsi pendampingan dan pemberian informasi dengan menggunakan platform online berakibat pada kurang optimalnya keberhasilan implementasi program kepada masyarakat sasaran. Pelaksanaan secara virtual memungkinkan masyarakat kurang paham akan praktik dan materi yang diberikan oleh petugas dalam proses pemberian layanan.

Pada dasarnya komunikasi pemerintahan merupakan wadah bagi pemerintahan untuk menyampaikan ide, gagasan, dan produk dari pemerintahan kepada masyarakat, namun di sisi lain situasi tersebut juga dapat dijadikan ruang bagi masyarakat untuk menyampaikan hal serupa, serta saran dan keluhan yang terjadi di tengah-tengah masyarakat. Dalam praktiknya pemerintahan memegang peranan penting dalam komunikasi pemerintahan, pemerintahan memiliki kewenangan sekaligus bertanggung jawab untuk mempertimbangkan, bahkan merespon keinginan-keinginan tersebut sesuai dengan aturan dan ketentuan yang berlaku (Rondonuwu et al., 2020).

Komunikasi pemerintahan memberikan pengaruh yang positif terhadap efektivitas penyelenggaraan kegiatan pemerintahan khususnya di sebuah daerah, salah satunya yaitu pemeliharaan hubungan. Ketika pemerintahan mempunyai jalinan komunikasi yang baik dengan masyarakat, hal tersebut dapat menjadi alat bagi mereka dalam mengoptimalkan kerja-kerja pelayanan migrasi kepada para PMI dan PMI Purna beserta anggota keluarganya. 
Komunikasi pemerintahan yang sedang dilaksanakan haruslah terlaksana dengan efektif. Komunikasi pemerintahan yang efektif memainkan peran utama dalam menginformasikan khalayak tentang pentingnya memiliki dokumen resmi dan berangkat menjadi PMI melalui jalur prosedural, informasi tentang pusat aduan di negara yang dituju, serta keamanan keluarga PMI yang ditinggalkan di kampung. Hal ini tentunya melibatkan komunikasi internal pemerintah di dalam dan di antara lembaga pemerintah dan komunikasi eksternal dengan publik (masyarakat), media, dan lembaga lain.

Dengan adanya keterkaitan kelompok dan organisasi yang berbeda itulah, komunikasi pemerintahan harus sangat efektif dan terkoordinasi dengan baik untuk memberikan informasi valid yang tersedia sehingga dapat membantu optimalnya pusat layanan migrasi, terutama di masa pandemi Covid-19.

\section{Metode Penelitian}

Penelitian ini menggunakan penelitian kualitatif. Bodgan dan Taylor menyebut pendekatan kualitatif sebagai prosedur penelitian yang menghasilkan data deskriptif berupa katakata tertulis atau lisan dari orang-orang atau perilaku yang diamati (Moleong, 2014). Berangkat dari penjelasan tersebut, dalam konteks tulisan ini, seorang peneliti mempunyai peran yang penting dalam keseluruhan proses penelitian yang dilakukan.

Metode yang digunakan dalam penelitian ini menggunakan pendekatan kepustakaan (library research). Menurut Zed (2003), dalam penelitian studi pustaka setidaknya ada empat ciri utama yang penulis perlu perhatikan di antaranya: Pertama, bahwa penulis atau peneliti berhadapan langsung dengan teks, bukan dengan pengetahuan langsung dari lapangan. Kedua, data pustaka bersifat "siap pakai" artinya peneliti berhadapan langsung dengan sumber data yang ada di perpustakaan. Ketiga, bahwa data pustaka umumnya adalah sumber sekunder, dalam arti bahwa peneliti memperoleh bahan atau data yang bukan orisinil dari data pertama di lapangan. Keempat, bahwa kondisi data pustaka tidak dibatasi oleh ruang dan waktu.

Berdasarkan hal tersebut, maka pengumpulan data dalam penelitian ini dilakukan dengan menelaah dan mengekplorasi beberapa jurnal, buku, dan dokumen-dokumen (baik yang berbentuk cetak maupun elektronik) serta sumber-sumber data dan atau informasi lainnya yang dianggap relevan dengan penelitian atau kajian.

\section{Hasil dan Pembahasan}

Kerangka teori yang dipakai untuk menganalisa pilar pertama yaitu pusat layanan migrasi Desmigratif adalah dengan menggunakan The Laswell Formula yang merupakan cara untuk menerangkan proses komunikasi menurut Harold Laswell. 


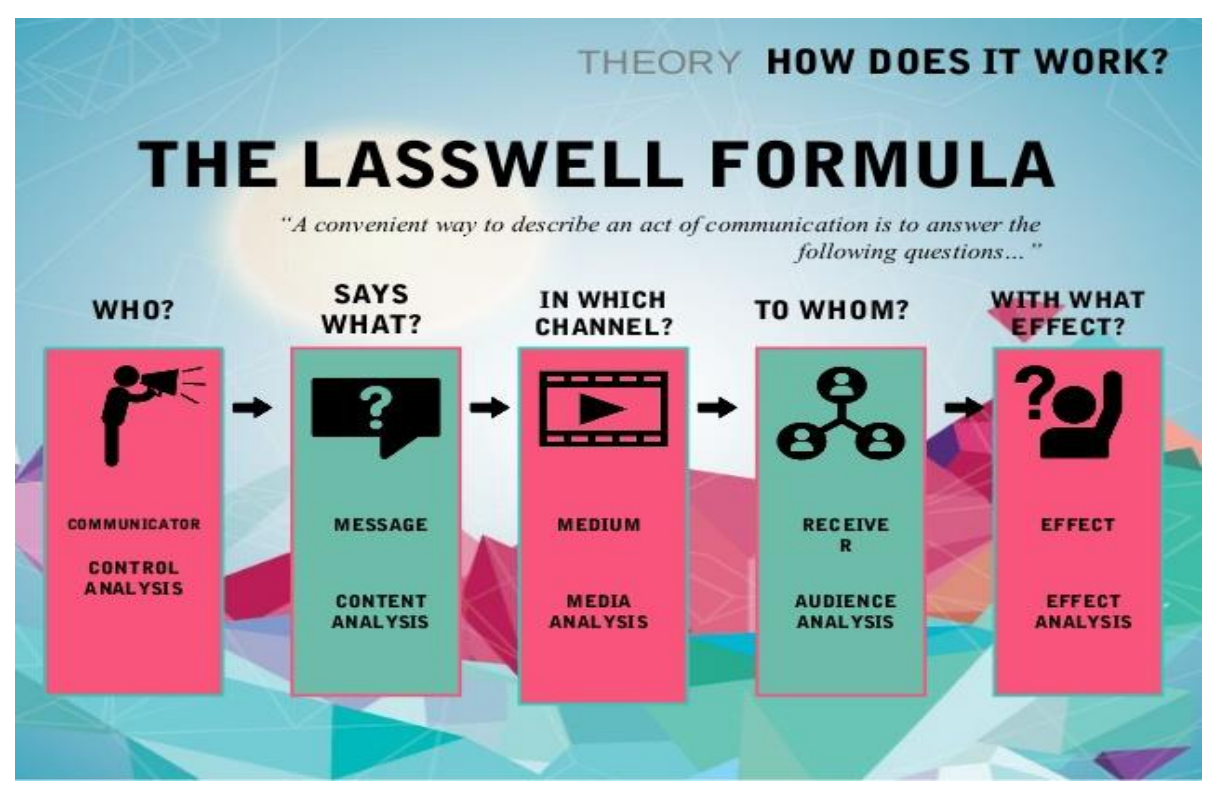

Gambar 1.2: The Laswell Formula

Fokus penelitian yang digunakan dalam penelitian ini merujuk pada teori Laswell, yaitu Who Says What in Which Channel To Whom With What Effect. Satu, Who/Komunikator. Who dapat diartikan sebagai orang yang memberi pesan atau komunikator, yaitu pihak yang mempunyai kebutuhan untuk melakukan komunikasi dan yang memulai suatu komunikasi terjadi. Dalam tulisan ini komunikator adalah warga desa atau bagian dari pemerintahan desa yang ditunjuk dan/atau dipilih oleh kepala desa untuk menjadi petugas desmigratif. Dua, Say What/Massage/Pesan. Say What merujuk pada hal apa yang akan disampaikan komunikator kepada sasaran yang akan dia ajak untuk melakukan komunikasi. Dalam tulisan ini pesan yang akan dikomunikasikan komunikator kepada penerimanya adalah mengenai informasi pasar kerja, informasi tata cara bekerja ke luar negeri, pengurusan dokumen awal, serta jaminan keamanan untuk keluarganya yang ditinggal di kampung halaman.

Tiga, In Which Channel/Saluran/Media. In Which Channel merujuk pada alat atau media yang digunakan komunikator untuk menyampaikan pesan kepada penerimanya, baik secara langsung melalui tatap muka maupun secara tidak langsung melalui media cetak/elektronik. Pada tulisan ini media yang digunakan adalah alat media elektronik yaitu grup-grup media sosial melalui aplikasi yang beredar di lingkungan masyarakat desa. Empat, To Whom/Penerima Pesan. Penerima pesan atau biasa juga disebut komunikan merujuk pada seseorang, baik berupa individu, kelompok, organisasi, lembaga, atau dengan bentuk perkumpulan yang lebih besar. Dalam tulisan ini, komunikan adalah para PMI, PMI purna, keluarga PMI, dan kelompok potensial untuk mendaftarkan diri sebagai PMI. Lima, With What Effect/Dampak atau efek. With What Effect merujuk pada efek yang terjadi pada komunikan setelah menerima pesan dari komunikator. Dalam tulisan ini efek yang dilihat adalah terjadinya perubahan pengetahuan atau sikap dari PMI di desa yang sudah ditetapkan sebagai Desmigratif. Selanjutnya, untuk desain programnya menggunakan komunikasi pemerintahan yang efektif dengan menempatkan suatu permasalahan sebagai Complex Intergovernmental Problems (CIP) sebagaimana menurut Schertzer. 


\section{Fenomena Konteks Petugas Desmigratif dan PMI}

Realitas menunjukkan bahwa desa-desa yang berkantong PMI, mayoritas merupakan desa dengan tingkat pendidikan warganya yang rendah, tingkat ekonominya serta tingkat kesejahteraannya di bawah rata-rata. Beberapa daerah dengan kondisi demikian dan menjadi pemasok TKI terbanyak ke luar negeri secara berturut-turut adalah Indramayu, Lombok Timur, Cirebon, Cilacap, dan Lombok tengah (Wahyuni, 2015). Kondisi seperti ini pada gilirannya berdampak pada kurang pedulinya para calon PMI di desa yang berkaitan dengan informasi mengenai peraturan perlindungan PMI.

Petugas Desmigratif yang berperan sebagai komunikator merupakan unsur komunikasi yang bertindak sebagai penyampai pesan kepada komunikan, yaitu PMI, PMI purna, anggota keluarga PMI, dan atau kelompok yang berpotensi seperti kelompok remaja yang menjelang lulus sekolah tingkat SMA. Sesuai arahan pemerintahan pusat, idealnya petugas desmigratif dalam menjalankan tugasnya menempuh cara atau metode door to door kepada sasaran atau komunikan.

Pada faktanya, metode kunjungan door to door tersebut tidak selalu berjalan dengan efektif. Penelitian Putri \& Nugroho (2020) menunjukkan bahwa metode door to door tidak dapat digunakan dan berjalan dengan baik, mengingat profesi para keluarga PMI di desa yang ditelitinya mayoritas bekerja sebagai petani. Sebagai alternatifnya, petugas Desmigratif yang bekerja, mengunjungi salah satu toko milik warga yang terkenal ramai dan sekaligus menjadi tempat berkumpulnya anak-anak yang berusia siap kerja (lulus SMA). Di toko tersebutlah, petugas melakukan sosialisasi dan penyuluhan mengenai gambaran umum tentang Desmigratif, kemudian memberikan arahan bagi mereka yang ingin meneruskan bekerja menjadi PMI untuk selanjutnya bisa datang ke kantor desa di ruang layanan migrasi.

Fakta lain juga menunjukkan bahwa para PMI, PMI Purna, dan keluarga PMI rata-rata kesulitan mendapat informasi yang disebabkan oleh kurangnya pengetahuan sehingga dengan mudah tertipu oleh oknum calo yang menawarkan mereka masuk menggunakan jalur non prosedural (Awwal et al., 2020).

Selain itu realitas di lapangan juga menunjukkan bahwa terdapat kendala pada pendampingan yang dilakukan selama masa pandemi Covid-19. Hal ini berkaitan dengan terbatasnya jangkauan pemberdayaan kepada masyarakat usia tertentu. Pemberdayaan dan pendampingan yang dilakukan secara virtual berimbas pada tidak optimalnya target sasaran pemberdayaan yaitu PMI purna yang sudah berusia lanjut untuk dapat mengakses informasi dan pelatihan yang disediakan serta diselenggarakan.

\section{Fenomena Konteks Pesan dan Media yang Digunakan}

Desa-desa berkantong PMI yang telah aktif mengoperasikan pusat layanan migrasi biasanya memberikan informasi seputar prosedur dan semua kebutuhan yang harus dipenuhi oleh PMI yang akan berangkat untuk bekerja ke luar negeri. Penyampaian pesan tersebut dalam beberapa contoh sudah terlaksana di kantor desa dan secara door to door. Adapun media pendukung yang digunakan biasanya berupa pamflet yang ditempel di papan pengumuman desa (Putri \& Nugroho, 2020).

Selain itu, media tambahan lainnya adalah dengan memanfaatkan kerja sama atau kolaborasi yang telah dijalin bersama instansi-instansi atau biro jasa (Calon Pekerja Migran Indonesia) CPMI yang sudah tersedia di desa yang bersangkutan. Hubungan ini merupakan 
simbiosis mutualisme, yang memudahkan bagi pemerintahan desa sebagai petugas desmigratif dan menguntungkan untuk para biro jasa CPMI.

Penelitian yang dilakukan oleh Nuraeni (2018), menunjukkan bahwa keberadaan mitra lokal sangat membantu efektivitas pelaksanaan program Desmigratif. Beberapa mitra lokal yang dapat diandalkan untuk membantu memberikan motivasi, pelatihan, pembinaan, pendampingan dan bantuan pemodalan kepada sasaran penerima manfaat Desmigratif sehingga dapat membangun maupun mengembangkan usaha yang telah dirintis, di antarnya adalah: a) Lembaga kemasyarakatan berupa tim penggerak PKK dan Karang Taruna. Tim penggerak PKK akan lebih mudah melakukan pendekatan kepada ibu-ibu rumah tangga sedangkan karang taruna akan lebih mudah melakukan pendekatan pada masyarakat usia muda, b) Lembaga Ekonomi dan Kelompok Usaha; Keberadaan Lembaga ekonomi berupa koperasi dan BUMDES diharapkan akan sangat berperan dalam membantu masyarakat untuk dapat membangun dan mengembangkan usahanya khususnya dalam permasalahan penyediaan bantuan modal dan upaya memperluas pemasaran produk usaha, c) Organisasi sosial, adat dan agama; Pada umumnya organisasi-organisasi tersebut memiliki pengaruh yang besar terhadap masyarakat, d) LSM dan tokoh peduli TKI.

Namun pada realitanya, beberapa fakta menunjukkan bahwa masih banyak calon PMI yang percaya informasi yang diberikan oleh oknum calo yang mencari keuntungan lewat mereka. Pesan yang biasa disampaikan oleh para calo yaitu seputar prosedur yang lebih mudah, gaji yang lebih besar, dan iming-iming kehidupan yang terjamin di negara tujuan PMI (Parwadi, 2012). Selain itu, masih lemahnya bank data di pusat layanan informasi, sehingga tidak mampu melacak dengan cepat warganya yang berangkat menjadi PMI dengan jalur ilegal. Padahal pelaksanaan Desmigratif menganut prinsip kolaboratif yang mengharuskan petugas Desmigratif bekerja sama dengan berbagai lini sektor di berbagai tingkatan pemerintahan.

Penelitian yang dilakukan oleh Nuraeni (2018) juga menunjukkan bahwa kendala belum maksimalnya kualitas sinyal menjadi salah satu faktor penghambat dalam pelaksanaan Desmigratif, khususnya pemberian layanan informasi migrasi. Kondisi seperti demikian jelas lebih sulit dihadapi di masa pandemi. Masyarakat kesulitan karena mereka harus melakukan usaha lebih untuk mendapatkan keterjangkauan akses internet yang digunakan sebagai media pendampingan dari mitra sebagai keberlanjutan program pemberdayaan.

\section{Analisis Dampak yang Terjadi pada PMI}

Perubahan pengetahuan dan perubahan perilaku pada PMI yang akan berangkat ke luar negeri tidak terlalu signifikan. Hal tersebut ditunjukkan dengan masih adanya golongan PMI yang berangkat dengan menggunakan jalur ilegal atau non-prosedural (Parwadi, 2012). Perubahan pengetahuan terjadi tidak merata. Golongan usia lanjut atau PMI purna tidak dapat mengakses informasi/pelatihan yang dilakukan secara daring (Dewi, 2020). Adanya desa-desa yang menjadi percontohan Desmigratif di beberapa daerah pada kenyataannya tidak mampu menekan minat masyarakat untuk menjadi PMI.

\section{Model Optimalisasi Pusat Layanan Komunikasi Desmigratif}

Model optimalisasi pusat layanan komunikasi desmigratif yang dapat dikembangkan, khususnya di masa pandemi Covid-19 adalah dengan menempatkan Covid-19 sebagai Complex Intergovernmental Problems (CIP). Sebagaimana dikemukakan Schertzer, dengan menempatkan Covid-19 sebagai CIP, seluruh elemen pemerintahan yang terkait dalam program Desmigratif ini wajib memahami bahwa dalam menghadapi CIP dibutuhkan pola-pola komunikasi yang tidak 
konvensional, melainkan pola komunikasi yang luar biasa (Ardiyanti, 2020). Pola komunikasi yang dibangun haruslah keluar dari lingkaran mainstream dengan mencoba sesuatu yang baru dan tentunya dilakukan secara berkelanjutan.

Alternatif solusi kedua, bisa dengan menerapkan komunikasi resiko sebagai pertimbangan utama, sehingga komunikasi pemerintahan harus disesuaikan dengan kelompokkelompok yang berbeda (Ardiyanti, 2020). Salah satu contohnya, jangkauan sasaran berdasarkan usia, pemerintah bisa mengklasifikasi mana golongan muda dan golongan tua untuk membantu mempermudah efektivitas penyampaian pesan. Selain itu komunikasi pemerintahan juga harus memperhitungkan aspek perilaku bagaimana orang bereaksi dan bertindak atas saran dan informasi yang diterima. Hal ini dalam artian, pemerintah tidak lengah dan sudah siap siaga dengan berbagai opsi atas segala kemungkinan yang terjadi.

Berdasarkan kajian yang dilakukan oleh Kementerian Ketenagakerjaan bekerjasama dengan LKKNU yang diwujudkan dalam Workshop Pengembangan Program Community Parenting Desmigratif, di Bekasi pada tanggal 28-29 Desember 2020, model optimalisasi pusat layanan komunikasi Desmigratif bisa diwujudkan dengan menempuh beberapa hal berikut ini:

a. Bentuk Pusat Layanan Informasi Desmigratif

Layanan Informasi Desmigratif lebih adaftif terhadap perkembangan teknologi tetapi tetap sensitif dengan realitas dan kondisi di sekitar. Pelibatan warga atau tokoh masyarakat yang mempunyai pengaruh untuk terlibat menjadi petugas dengan sebelumnya diikutkan pelatihan Desmigratif di kementerian terkait yang menyelenggarakan. Dilakukan upaya memperluas jaringan dengan biro jasa atau penyedia layanan untuk calon PMI yang legal, tidak merugikan masyarakat, serta akuntabilitasnya teruji. Di samping itu juga membuat komunitas virtual (bisa melalui media Whatssap atau Facebook) antara petugas dengan tokoh masyarakat untuk membagikan informasi, melakukan pelatihan, serta memonitor dan mengantisipasi masuknya calo serta menjadikannya sebagai ruang berbagai informasi. Melakukan penguatan kapasitas petugas desmigratif, petugas desa dan BLK melalui media grup di media sosial.

b. Aspek Kunci Pusat Layanan Informasi Desmigratif

Aspek kunci pusat layanan informasi desmigratif lebih modern, tidak monoton dan terikat waktu serta tempat (fleksibel), adanya peningkatan kapasitas petugas Desmigratif, dan terdapat kapasitas menggerakan masyarakat.

c. Prinsip Pusat Layanan Informasi Desmigratif

Prinsip pusat layanan informasi Desmigratif berpusat pada tersampaikannya informasi, perspektif hak PMI dan keluarganya, pemanfaatan kearifan dan potensi local, sinergi gotongroyong, dan kreativitas.

d. Ekosistem Pusat Layanan Informasi Desmigratif

Ekosistem pusat layanan informasi Desmigratif memiliki sasaran langsung program, yaitu PMI, PMI purna, keluarga PMI, kelompok potensial PMI. Sedangkan sasaran antara, yaitu petugas Desmigratif, penanggungjawab Desmigratif, BLK, dan Kasi Kesra Desa.

e. Inovasi Pusat Layanan Informasi Desmigratif

Beberapa inovasi di Pusat Layanan Informasi Desmigratif adalah: (1) Membuat grup di media sosial yang di dalamnya beranggotakan para sasaran penerima informasi. Bagi yang tidak terjangkau karena alasan keterbatasan ekonomi, bisa menggunakan media cetak berupa surat yang berisikan informasi yang serupa. Opsi lainnya informasi bisa disampaikan oleh 
tetangga atau anggota keluarga lainnya yang tergabung di dalam grup. Prinsipnya, dalam satu keluarga PMI, ada perwakilan yang masuk dalam grup yang dibuat oleh petugas Desmigratif. (2) Adanya pendampingan langsung dari golongan usia yang lebih muda dalam menggunakan platform video conference sebagai media dalam pelatihan dan pemberdayaan secara daring, yang diberikan kepada golongan usia tua atau PMI purna. (3) Peningkatan Kemampuan SDM dibidang Teknologi Informasi. Salah satunya bisa dalam variasi bentuk informasi yang disebar. Tidak hanya berupa teks panjang, bisa menggunakan video yang mudah dicerna, voice note, atau gambar. (4) Berkelanjutan. Permasalahan dalam pendampingan dari pelaksanaan agenda-agenda yang dilakukan oleh lembaga pemerintah maupun non pemerintahan biasanya masih terkendala dalam keberlanjutan serta sinergitas program ang satu dengan yang lainnya. Oleh karena itu, proses pendampingan yang berkelanjutan sangat penting untuk direalisasikan.

f. Jenis Keahlian Baru bagi Para Petugas Desmigratif

Adapun jenis keahlian baru bagi Para Petugas Desmigratif adalah cakap menggunakan alat elektronik, pembuatan konten, serta update dengan hal-hal baru dan menarik;

\section{Kesimpulan}

Pusat layanan informasi desmigratif harus lebih adaptif dengan perkembangan zaman, menyesuaikan dengan pesatnya perkembangan teknologi, dan menyasar komunikan atau target yang tepat dengan pilihan media yang digunakan. Kiat seperti ini, terutama sangat dibutuhkan di era pandemi Covid-19 seperti sekarang ini. Pelayanan pemerintah yang harus menyesuaikan dengan protokol kesehatan dalam konteks ini yaitu social distancing, membuat kesempatan untuk memberikan pelayanan secara langsung, baik di kantor desa maupun melalui door to door menjadi sangat terbatas. Maka alternatifnya adalah pemberian pelayanan, khususnya desiminasi informasi melalui pemanfaatan alat elektronik dan aplikasi yang tersedia di dalamnya. Dalam pelaksanaannya, untuk memenuhi kebutuhan masyarakat maka pemerintahan dituntut untuk menjalin kolaborasi yang bertumpu pada Electronic Governance.

\section{Daftar Pustaka}

Ardiyanti, H. (2020). Komunikasi Pemerintahan Dalam Penanganan Pandemi Covid-19. Bidang Politik Dalam Negeri Info Singkat: Kajian Singkat Terhadap Isu Aktual Dan Strategis, 12(15), 25-30.

Awwal, H. M., Sihabudin, A. A., \& Sunarti, N. (2020). Pelaksanaan Program Desa Migran Produktif Di Desa Karyamukti Kecamatan Banjaranyar Kabupaten Ciamis. Moderat: Jurnal Ilmiah Ilmu Pemerintahan, 6(3), 573-584.

Bnp2tki. (2018). Informasi Pelayanan Pengaduan Crisis Center BNP2TKI. Portal.Bnp2tki.Go.Id. http://portal.bnp2tki.go.id/read/13488/Informasi-PelayananPengaduan--Crisis-Center-BNP2TKI.html

Dewi, W. A. F. (2020). Dampak COVID-19 terhadap Implementasi Pembelajaran Daring di Sekolah Dasar. EDUKATIF: Jurnal Ilmu Pendidikan, 2(1), 55-61. https://doi.org/10.31004/edukatif.v2i1.89

Fitriani, Y., Suroso, B. U., \& Puspawati, A. A. (2020). Analisis Implementasi Pilar Penumbuhkembangan Usaha Produktif Di Desa Migran Produktif (Desmigratif) Jepara Kabupaten Lampung Timur. Seminar Nasional Penelitian Dan Pengabdian Kepada Masyarakat) Tahun 2020, 490-498.

Ikrimah, A., Martha Lingga, B., Bagus Prasetia, I., Achmad Baharudin, F., Yogananta, M., \& 
Antriyandarti, E. (2020). Desain Program Pendampingan Optimasi Remittance Rumah Tangga Tenaga Kerja Indonesia (TKI) di Desa Migran Produktif Mojorejo, Karangmalang, Sragen. Journal of Agribusiness and Community Empowerment, 3(2), 124-134.

Karyati, S., \& Adiwirahayu, A. (2018). Strategi Pelaksanaan Program Desa Migran Produktif Di Desa Kuripan Kecamatan Watumalang Kabupaten Wonosobo. Jurnal Pembangunan Masyarakat Dan Desa, 27(2).

Kemnaker. (2019a). Peraturan Menteri Ketenagakerjaan tentang Pemberdayaan Komunitas Pekerja Migran Indonesia di Desa Migran Produktif. Jdih.Kemnaker.Go.Id. https://jdih.kemnaker.go.id/asset/data_puu/Permen_2_2019.pdf

Kemnaker. (2019b). Petugas Desmigratif Diminta Bantu Pendataan Pekerja Migran. Kemnaker.Go.Id/. https://www.kemnaker.go.id/

Kurniawan, A. (2019). Tingkatkan Perlindungan Pekerja Migran, Kemnaker Galakkan Desmigratif. Kompas.Com. https://kilaskementerian.kompas.com/kemnaker/read/2019/08/07/192416526/tingkatkanperlindungan-pekerja-migran-kemnaker-galakkan-desmigratif

Moleong, L. J. (2014). Metodologi Penelitian Kualitatif Edisi Revisi. PT. Remaja Rosdakarya.

Nuraeni, Y. (2018). Strategi Pengembangan UMKM Berbasis Agroindustri Melalui Program Desa Migran Produktif (Desmigratif) Dalam Rangka Perluasan Kesempatan Kerja. Jurnal Akuntansi Manajerial, 3(1), 42-53.

Parwadi, R. (2012). Penyimpangan Kebijakan Pengiriman TKI ke Luar Negeri. Jurnal Kebijakan Publik, 3(1), 9-15.

Putri, S. K., \& Nugroho, A. (2020). Pelaksanaan Program Desmigratif Sebagai Upaya Pengurangan Jumlah Pekerja Migran Indonesia Non Prosedural Di Desa Arjowilangun Kabupaten Malang. NOVUM: Jurnal Hukum, 7(4), 173-188.

Rondonuwu, J., Kawengian, D. D. V., \& Himpong, M. D. (2020). Peran Komunikasi Pemerintahan Dalam Menyosialisasi Prosedur Tetap (Protap) Kesehatan Pandemi Covid-19 Di Masyarakat Dumoga Timur. Acta Diurna Komunikasi, 2(4), 1-17.

Wahyuni, N. D. (2015). 5 Daerah Pemasok TKI Terbanyak ke Luar Negeri. Liputan6.Com. https://www.liputan6.com/bisnis/read/2186368/5-daerah-pemasok-tki-terbanyak-ke-luarnegeri

Zed, M. (2003). Metode Penelitian Kepustakaan. Yayasan Obor Indonesia. 